\title{
Water managers' perspectives on reservoir operations for sustainable irrigation in Alberta
}

\author{
M.-È. Jean \& E. G. R. Davies \\ Department of Civil and Environmental Engineering, \\ University of Alberta, Canada
}

\begin{abstract}
Sustainable reservoir management is essential to ensure the productivity of agriculture and to adapt to a changing climate. Despite progress in reservoir modelling and management with the improvement of computer capabilities and the development of optimization methods, managers and decision-makers still face the challenge of applying the output of more-theoretical optimization models to real-world reservoir operations. This research analyzes reservoir managers' perspectives in Alberta's heavily-allocated South Saskatchewan River basin, in order to improve understanding of the behaviour of reservoir operators under different climatic and hydrological conditions. The method involves in-person interviews with twelve water managers of Southern Alberta's irrigation districts. The data collected suggest that seniority-based allocation priorities are generally not strictly applied. Instead, cooperation between districts and between irrigators within a district indicates that water allocations are driven principally by the infrastructure capacity on a river-basin-scale basis. Of additional importance is recognition of the "day-by-day" approach adopted by all water managers interviewed who will "never sacrifice today for tomorrow". Moreover, water managers do not apply annual or multi-year water deficit-distribution strategies, but instead impose variable water rationing for all irrigators at the beginning of a growing season. The contribution of this research is to provide real-world data and a better understanding of water managers' perspectives that may lead to more valuable outcomes from modelling studies, and results that may be more readily adopted by water managers.

Keywords: irrigation, operators' decision-making, optimization models, reservoir operations, stakeholder interviews.
\end{abstract}




\section{Introduction}

Sustainable reservoir management for irrigation is essential to ensure agricultural productivity over the near- to medium-term, and to adapt to a changing climate over the longer term (Lenton [1]). With the global population projected to reach about 9.5 billion by 2050 (United Nations [2]), irrigated agriculture will become even more essential to meet food requirements, since irrigation enhances both agricultural reliability and productivity. There is a need for optimizing the operations of reservoir systems to cope with future water demands (Ahmad et al. [3]) while ensuring environmental integrity of water resource systems (Loucks [4]). Literature has described the state-of-the-art in optimization of reservoirs systems operations $[3,5]$, but, despite progress in reservoir modelling and management, decision-makers and reservoir managers still show resistance to application of the output of computer-based optimization models to real-world reservoir operations [5-8]. As emphasized by Labadie [5], the involvement of reservoir managers in model development can help bridge the gap between theory and practice, and as a result, innovative advances in water resources management would not be limited to theoretical applications.

In the South Saskatchewan River Basin (SSRB), Alberta, Canada, numerous dams are operated for irrigation, which accounts for $60-65 \%$ of the province's annual water consumption (Alberta Environment and Sustainable Resource Development [9]). However, growing water conflicts with a rising population and increasing economic development, changing supply and demand with climate change, and an increasing emphasis on ecological concerns all threaten water availability in the SSRB (Martz et al. [10]). Water resources modeling studies have been conducted to assess the effects of these changes and to minimize future drought impacts [11-13]. This research analyzes reservoir managers' perspectives in order to improve the applicability of reservoir management theory in Alberta's most allocated river basin, the SSRB.

\section{Methodology and research context}

This research aims to improve understanding of the decision-making criteria of reservoir operators under different meteorological and hydrological conditions. The project has investigated water managers' practices through in-person interviews with water managers and water operators of Irrigation Districts in Southern Alberta, as well as with water planners from the provincial government. The interview questions were designed to connect reservoir operators' practices with optimization model development.

A previous study attempted to understand operators' decisions by analysing the relationships of historical releases of 79 reservoirs in California and the Great Plains to factors such as current inflow, previous releases and previous storage using mutual information, a nonlinear approach (Hejazi et al. [14]). Similarly to our study, Toebes and Rukvichai [15] interviewed reservoirs' managers for their work on the daily operations of the Green River Basin multipurpose reservoirs system located in Kentucky, USA. They documented informal procedures 
developed by the operators in order to minimize the deviations between their optimization model and historical reservoir releases.

Table 1 presents information on the thirteen Irrigation Districts (IDs) of Southern Alberta. The licensed water supply and average gross diversion volumes for the last five years $\left(\mathrm{GD}_{5 \mathrm{y}}\right.$ for 2009-2013) give an idea of their relative size. Their internal water storage capacity (ISC), which corresponds only to the reservoirs they own, their total water storage capacity (TSC), which includes both internal and provincially-owned reservoirs and the ratio of storage capacity over the $\mathrm{GD}_{5 \mathrm{y}}$, could indicate how well an ID is supported by reservoirs.

The $\mathrm{GD}_{5 \mathrm{y}}$ is not always a good indicator of an ID's storage capacity as provincially-owned reservoirs can serve other purposes than irrigation, including flood mitigation and recreation, and the configuration of each ID's canal network means that irrigators may rely entirely on river diversions if they are not downstream of a reservoir. Finally, "y" indicates that the district was visited or interviewed for this study, while " $n$ " indicates no visit or interview. The numerical values presented in Table 1 are calculated from published data of the Alberta Agriculture and Rural Development [16].

\section{Results and discussion}

\subsection{Optimization modelling vs cooperative management}

Optimization models for reservoir operations use an objective function, decision variables, and constraints to define mathematically the costs and benefits related to optimal reservoir operations, water supply allocations and physical characteristics of the water network $[8,17]$. Many optimization models in Western Canada, such as the Government of Alberta's Water Resources Management Model, are based on the water license system. This type of model derives an optimal allocation of water subject to the priority of use of each licensee (Ilich [18]). Indeed, in the Alberta's Water Act, senior licensees have the right to divert their full allocated volume of water before junior licensees divert any amount. If the allocated volume is greater than the licensee's capacity to divert water, the user's right to water becomes limited to the volume and rate his conveyance system is capable of carrying (Province of Alberta [19]).

However, the data collected for this study suggest that the seniority-based allocations of senior versus junior water users are not generally applied in realworld reservoir operations [20-25]. Richard Phillips, the general manager of the Bow River Irrigation District (BRID), states that the water priorities are "meaningless" because no "priority call" has ever been made in the Bow River Basin. Similarly, Erwin Braun, the general manager of the Western Irrigation District (WID), says that district personnel have discussed the sharing of river flows when there are shortfalls. In such cases, the districts with stored water have temporally reduced their water diversions from the river even if their license priority allows them to withdraw more. According to one interviewee, in times of shortfalls "one of us does not take its water, so the others can catch up" [26], and 


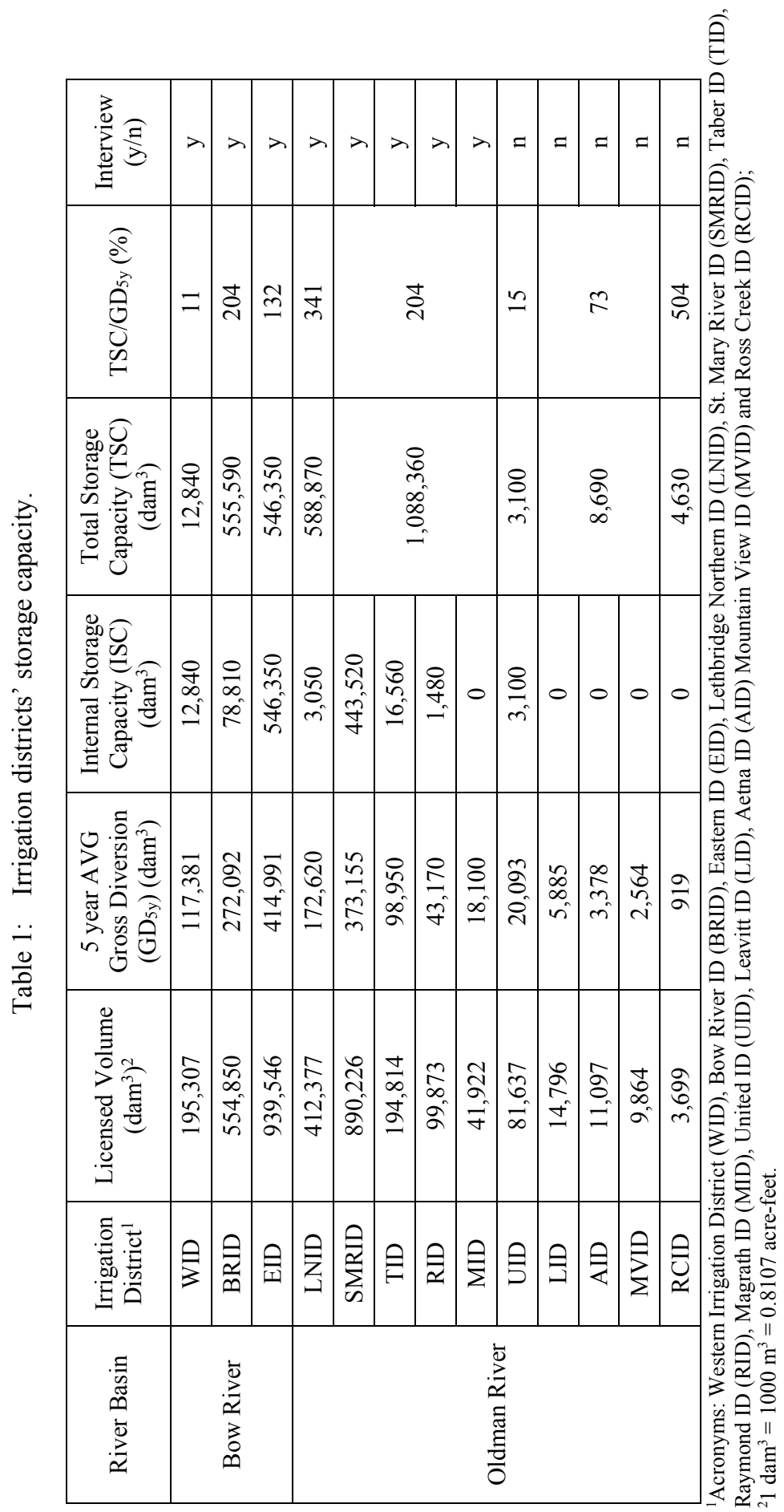


another adds, "The principle is: if there are shortfalls, all the ID's and irrigators share the shortfall evenly" (Braun [21]). Similarly for the Oldman River Basin, "even if the St. Mary River Irrigation District (SMRID) has an older license, they share the water with the junior licenses in times of water shortage", according to Jan Tamminga, SMRID's manager of operations.

In optimization models driven by unique water licence seniority rankings, realworld cooperation and more flexible diversion schedules employed by the IDs are not captured. More realistic optimal results could therefore be obtained under a better representation of basin-scale cooperation.

\subsection{Reservoir management}

\subsubsection{Reservoir rule-curves}

Reservoir rule-curves guide reservoir releases to meet water supply and other water use objectives [27, 28]. For example, the US Army Corps of Engineers [28, 29] described a zone-based policy (ZBP) which specifies seasonal storage elevation targets for each reservoir purpose. The ZBP can also be used to manage a single-purpose reservoir, particularly one for water supply, providing that each zone specifies release reductions to allow water conservation when storage decreases. The literature also describes other theoretical rule-curves for reservoir releases which are based on the available water supply and the water demand such as the standard operating policy (SOP) or the hedging rules policy (HRP) [27, 28]. Figure 1 and Figure 2 show the ZBP, SOP and (simple) HRP curves.

In Figure 1, the flood control zone provide room for flood runoff while the conservation zone is the ideal level to maintain in the reservoir for ensuring water supply without affecting flood mitigation measures and finally the buffer zone is the minimum storage to maintain for water supply when water conservation is necessary. In Figure 2, the SOP is appropriate when meeting the immediate downstream demand has the highest priority. However, when future inflows are likely insufficient to meet downstream demand and the losses generated by the water deficits are non-linear - i.e. when "the severity of shortages is more important than their frequency" (Lund [28]) - the HRP becomes more appropriate. Similarly to the ZBP applied for a single-purpose reservoir, the HRP aims to minimize impacts of future water shortages by not supplying the totality of the demand in the short term (Beard et al. [29]); multiple variations of the HRP have been developed based on the form of the deficit's loss function (Hashimoto et al. [30]). Explicit reservoir rule-curve definitions are not always provided in optimization models, because some models automatically derive optimal reservoir storage under a user-specified objective function. Such optimization models can then be used to re-evaluate existing reservoir operations of a reservoir system [8, 29].

In practice, the IDs assume that "every day is the first day of the next drought" [26]. Therefore, their water managers aim to fill their reservoirs as full as possible, as early as possible, in the irrigation season [20-26, 31]. Indeed, for the first half of the irrigation season when the river stage is higher, the diverted water will serve 


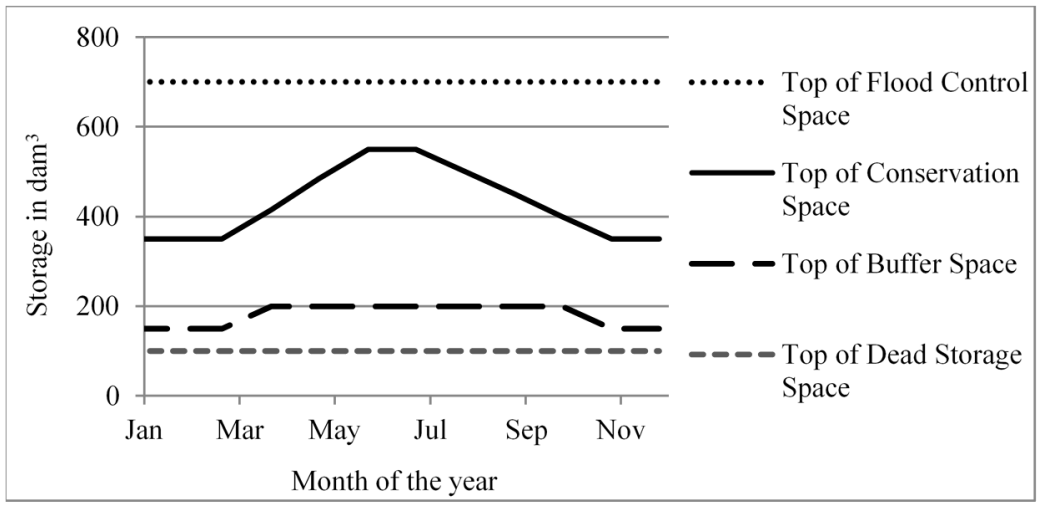

Figure 1: ZBP adapted from Beard et al. [29].

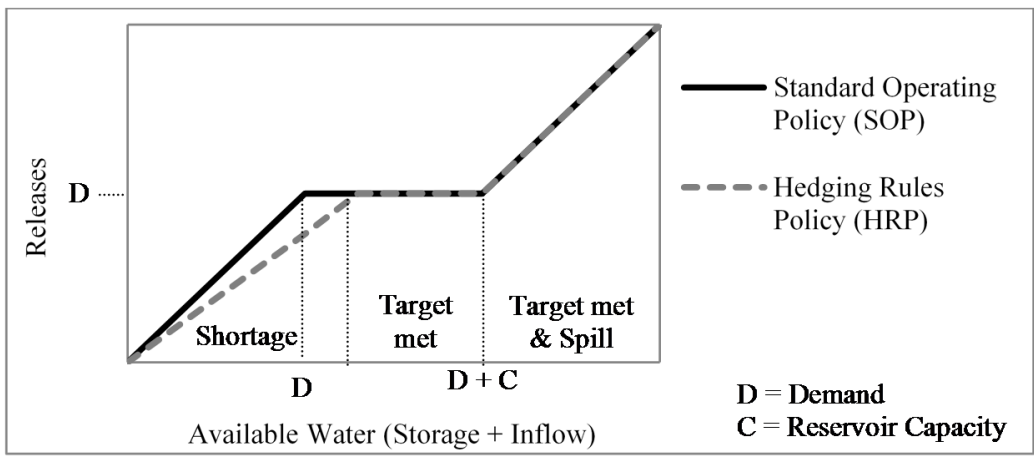

Figure 2: $\quad$ SOP and HRP adapted from Lund [28].

two purposes: providing water for irrigation, and filling the larger reservoirs to their full capacity before the river stage decreases in late summer. The IDs' licences prescribe maximum withdrawal rates subject to the river flow (Alberta Environment and Sustainable Development [32]). If the demand is greater than the licensed river withdrawals, reservoirs can be depleted; otherwise all the demand is met by diversions from the river. However, in late summer when the river is low, the IDs can supply the irrigation demand by using the water stored in their reservoirs as they start gradually to deplete the reservoirs levels to the winter levels. In this way, the impact of irrigation on riparian and fish habitats is minimized.

The districts operate their smaller reservoirs as "balancing reservoirs" (Gallagher [31]), which means that they are used to supply existing demands until new water diversions from the river can refill them. These reservoirs thus improve the speed of delivery to most downstream users, and provide the district with more flexibility in the delivery of water. The IDs refill smaller reservoirs first because their lower storage capacity increases the vulnerability of downstream users [26] which differs from USACE's rule of "fill the higher (upstream) reservoirs first, 
and the lowest (downstream) last"; note that the aim of the USACE's rule is to maximize the amount of water available by minimizing spilling at the downstream end of the system (Lund [28]).

Finally, note that carry-over storage, from one year to the next, is limited since reservoir levels must be lowered during winter to prevent ice damage on reservoir structures and banks as well as allowing the districts to catch June's rain and the snowmelt runoff. The second objective of the winter level is of particular importance for multiple-purpose reservoirs used for flood control in addition to water supply. Even if the reservoirs are depleted for winter, there is still live storage available for the next year. However, in particularly dry years, the reservoirs could be depleted below their winter levels as the IDs normally do not prioritize carry-over storage over meeting current demand. As a consequence, if the snow cover is lower than usual and if the spring is dry, the districts start the irrigation season with a lower supply [20-26, 31]. In such cases the districts "just hope for more water to come" (ZoBell [25]).

The actual practice in the IDs interviewed is similar to the ZBP shown in Figure 1 with the difference than no conservation zones are developed. Indeed, the IDs aim to maintain the reservoir levels in an acceptable zone, which varies seasonally from summer to winter. Some multiple-purpose reservoirs have a water-supply and flood-control zone, while single-purpose reservoirs only have one target elevation based on the reservoir's physical capacity.

\subsubsection{Day-by-day management}

Also important is recognition of the "day-by-day" approach adopted by all water managers interviewed, who will "never sacrifice today for tomorrow" (Phillips [23]). Districts' reservoir release decisions depend on today's water availability and today's water demand, and do not consider tomorrow's possible risks [20-26, 31]. There are recognized dangers to this approach: in 2000, SMRID let its irrigators use all the water they wanted while the river flows were low, which lowered the reservoirs more than usual before winter; the impact of dry conditions in 2001 was therefore worse. Their philosophy was to use the water when there was a known economic value to be obtained from it, because they did not know the conditions for the next year. Thus, they adopt a rather passive approach. Toebes and Rukvichai similarly noted from their interviews with reservoir managers that daily operational deviations from the established rule-curve are not related to previous release decisions: "the plots should not be given any cumulative interpretation" [15]. In terms of modelling, this approach correlates well with the "single timestep optimization (STO)" method used in most river basin models, which optimizes allocations at each simulation timestep without considering future or past allocations (Ilich [18]).

\subsubsection{Medium-term planning}

In order to minimize the losses in their reservoir systems and operate their hydraulic structures with minimal adjustment, the IDs have to anticipate their water supply versus water demands [20-26, 31]. Indeed, even if the districts base their operations upon delivery requests (the water demands from irrigators), experience helps district "ditchriders" (those in charge of water delivery to the 
farm gate) and the district in general to anticipate demands and the losses by evaporation and seepage [20-26, 31]. Further, an interviewee explained that his district seeks to identify future trends in crop mix to schedule better the refill and draw down periods of its reservoirs, as some crops (such as seeds) require early moisture, while other crops require late irrigation (such as corn). When assessing future water demands and water supply, districts must coordinate their withdrawals with upstream and downstream users along the river reach and take into consideration the time of travel of the water $[21,23,26]$ which can be as much as a week (Tamminga [24]).

\subsubsection{Information used in operational decision-making}

In their daily operations of reservoirs, water operators base their decisions on different information. As explained by an interviewee, "any time you can gather more information to help you feel more comfortable with your decisions, it is better". The major information sources used by the IDs include,

- Water orders from the irrigators

- River flows (each water licence is subject to diversion rates that vary according to the river flows)

- $\quad$ Actual reservoir levels

- Weather forecasts (temperature and precipitation for the next week)

- $\quad$ Soil moisture reserves (general information provided by the irrigators)

- Actual flows in the conveyance system

- $\quad$ Recorded flows previously delivered to the irrigators

- $\quad$ Theoretical irrigation scheduling tools [26], such as the Alberta Irrigation Management Model software provided online by AARD [33]

In addition to information on current conditions, another important factor is the human dimension: the capacity of district staff to work closely with the irrigators as they can communicate easily with irrigators and can react quickly when necessary [20-26, 31].

\subsection{Drought mitigation}

\subsubsection{Water supply forecast}

The IDs also use data for planning the irrigation season before it starts. Every year before spring, the Government of Alberta forecasts the available water supply for irrigation by using the following data:

- Snow pack monitoring in the Rocky Mountains, upstream of the IDs

- Actual winter storage in the reservoirs

- $\quad$ Soil moisture values provided by AARD

- $\quad$ Normal, seasonal rainfall volumes

This information is published online and is used by the IDs to determine whether they should plan for rationing at the beginning of the season. They advise irrigators of conditions via newsletters or at annual meetings in the spring [20-26, 31]. The Government of Alberta reviews the estimation of the water supply every month during the growing season by updating the forecasts with actual data. The IDs can then decide whether to maintain or remove the "rationing mode" [20, 22, $24,25,31]$. The IDs also follow snowpack data, as it is a good indicator of 
conditions at the beginning of the season [21, 23, 26]. Indeed, for the Bow River Basin, average snow depth values in the Rocky Mountains indicate roughly whether enough water will be available for diversion from the river to meet irrigation demands and to fill reservoirs up to the end of June [21, 23].

\subsubsection{Water rationing}

As mentioned previously, water managers do not apply annual or inter-annual water deficit-distribution strategies, but instead impose water rationing for all irrigators at the beginning of a growing season. Each district decides on a maximum water allocation for normal to wet years, when no rationing is necessary; this allocation vary from 17 inches (ZoBell [25]) to 24 inches (Phillips [23]) based on districts' water storage capacity and distribution efficiency. However, some districts typically allow irrigators to divert more than the prescribed limit, as the majority of the irrigators will not use their full allocation $[24,26,31]$. In dry years, the allocation can be reduced to as low as 7 inches and is maintained more strictly for all users (Tamminga [24]). The rationing limit is based on the probable volume of water available for the season which varies for every district. In addition to application limits for individual irrigators, districts can have drought plans that extend to other users. For example, if EID had to apply water rationing for irrigation, the municipalities and other water users that draw from EID's canals would have to reduce their consumption equally to share the shortage, with no differentiation between junior and senior users [25, 26].

Water rationing was implemented in the three IDs of the Bow River Basin after the drought of 2001. During that year, the EID cut all water diversions for two weeks just before the end of the season (in September) to refill its reservoirs [26] and the WID imposed a rotation scheme that restricted the use of pivots to only one at a time (Braun [21]). In contrast, the BRID did not impose irrigation restrictions, and the media contributed to establishing a panic around the district which caused irrigators to try to store soil moisture for the next year, which unnecessarily depleted the reservoirs (Phillips [23]).

Under rationing, the IDs indicated that irrigators set their own management strategy before the start of the irrigation season by growing crops that require less water, applying water earlier in the season in order to store water in the soil, or transferring the water normally applied to low-value crops to high-value crops only. In the IDs of the Oldman River Basin, another adaptation strategy explored in 2001 was the sale of water between irrigators and other water users under formal authorization.

These findings contrast with theoretical optimization methods which aim to distribute the water supply deficit over a predetermined simulation time without considering irrigator's actual strategies at the beginning of the growing season. Indeed, the districts' release policies could be compared to the HRP (see section 3.2.3), with the difference that is not the released water that is temporarily reduced as a water conservation strategy, but rather the target demand (D) that is reduced. Therefore, approaches like "multiple timestep optimisation (MTO)", which aims to derive optimal reservoir rule curves based on perfect foreknowledge of water supply and water demand (Ilich [18]), should ideally incorporate early season 
adaptations as well. Of course, it is possible that the actual practices described above are non-optimal, compared with modelling results that are obtained without irrigators' adaptation strategies; however, an understanding of water managers' perspectives is nonetheless informative.

\section{Conclusion}

Sustainable management of irrigation is essential in ensuring food security under the challenges of a growing population and a changing climate. To improve reservoir management for irrigation, optimization models are used to allocate best the available water supply to meet the water demand and other objectives while minimizing the impact of water deficits under a set of constraints $[5,8,28]$. To be effective, the assessment of the fundamental behaviour of optimization models should be reviewed by incorporating more information from water managers such as the data they rely on and their decision processes $[5,14]$.

Interviews with irrigation district water managers demonstrated that their water management strategy for different climatic and hydrological conditions is a combination of experience and flexibility. The innovative contribution of these research findings is to provide real-world data and a better understanding of water managers' perspectives on reservoir management. The results suggest that the rules behind water allocations modelling should be oriented toward 1) basin-scale cooperation, 2) accounting for the effects of early-season water rationing, and eventually 3) day-by-day release strategies. The actual management practice in time of droughts consists of reducing water demands early in the season and managing by cooperation rather than hedging the water supply. Therefore optimization models should evaluate if more efficient water storage management could ensure enough water or if actually-preferred early-season adaptations lead to optimal water use. Although this study took place in Southern Alberta, where agriculture productivity relies on surface water diversions, the results are likely to help modellers from other regions of the world to understand water managers' behaviours in the context of competitive water uses.

\section{Acknowledgements}

The authors thank all the participants from Alberta's Irrigation Districts, who shared their experience and provided their insights. A particular acknowledgement is made to Richard Phillips and Alan Harrold for their review of the manuscript. The authors also acknowledge the Alberta Land Institute for financial support of the project.

\section{References}

[1] Lenton, R., Irrigation in the twenty-first century: Reflections on science, policy and society. Irrigation and Drainage, 63, pp. 154-157, 2014.

[2] United Nations (UN). Department of Economics and Social Affairs, Population Division Web Site, New York, www.un.org/en/development/ desa/population/ 
[3] Ahmad, A., El-Shafie A., Razali, S. F. M., Mohamad, Z. S., Reservoir Optimization in Water Resources: A Review. Water Resources Management, 28, pp. 3391-3405, 2014.

[4] Loucks, D. P., Sustainable Water Resources Management. Water International, 25(1), pp. 2-10, 2000.

[5] Labadie, J. W., Optimal operation of multi-reservoir systems: State-of-theart review. Water Resource Planning and Management, 130(2), pp. 93-111, 2004.

[6] Loucks, D.P., van Beek, E., Stedinger, J.R., Dijkman, J.P.M., Villars, M.T., Water resources systems modelling: its role in planning and management (Chapter 2). Water Resource Systems Planning and Management: An Introduction to Methods, Models and Applications, ed. UNESCO, Paris, pp. 38-58, 2005.

[7] Simonovic, S. P., Reservoir systems analysis: closing the gap between theory and practice. Water Resources Planning and Management, 118(3), pp. 262-80, 1992.

[8] Wurbs, R. A., Reservoir-System Simulation and Optimization Models. Water Resources Planning and Management, 119(4), pp. 455-472, 1993.

[9] Alberta Environment and Sustainable Resource Development. State of the Environment- Surface Water Pressure Indicators Web Site, www.esrd.alberta.ca/focus/state-of-the-environment/water/surface-water/ pressure-indicators/water-used-for-irrigation.asp

[10] Martz, L., Bruneau, J., Rolfe, J.T., Climate Change and Water SSRB Final Technical Report, pp. 2-4, 2007.

[11] Ali, K. \& Klein, K. K., Implications of current and alternative water allocation policies in the Bow River Sub Basin of Southern Alberta. Agriculture Water Management, 133, pp. 1-11, 2014.

[12] Islam, Z. \& Gan, T. Y., Effects of Climate Change on the Surface-Water Management of the South Saskatchewan River Basin. Water Resources Planning and Management, 140, pp. 332-342, 2014.

[13] Sheer, A. M. S., Nemeth, M. W., Sheer, D. P., Van Ham, M., Kelly, M., Hill, D., Lebherz, S. D., Developing a new operations plan for the Bow River Basin using collaborative modelling for decision support. American Water Resources Association, 49(3), pp. 654-668, 2013.

[14] Hejazi, M. I., Cai, X., Ruddell, B. L., The role of hydrologic information in reservoir operation - Learning from historical releases. Advances in Water Resources, 31, pp. 1636-1650, 2008.

[15] Toebes, G. H. \& Rukvichai, C., Reservoir system operating policy - case study. Water Resource Planning and Management Division, American Society of Civil Engineering, 104(WR1), pp. 175-191, 1978.

[16] Alberta Agriculture and Rural Development (AARD), Alberta Irrigation Information, Facts and Figures for the Year of 2013, Alberta Government: Lethbridge, pp. 1-30, 2014.

[17] Loucks, D.P., van Beek, E., Stedinger, J.R., Dijkman, J.P.M., Villars, M.T., Modelling methods for evaluating alternatives (Chapter 3). Water Resource 
Systems Planning and Management: An Introduction to Methods, Models and Applications, ed. UNESCO, Paris, pp. 59-80, 2005.

[18] Ilich, N., Improving real-time reservoir operation based on combining demand hedging and simple storage management rules. Journal of Hydroinformatics, 44(3), pp. 533-544, 2011.

[19] Province of Alberta, Water Act, Revised Statutes of Alberta 2000 Chapter W-3, Alberta Queen's Printer: Edmonton, pp. 24-34, 2010.

[20] Anderson, C., Personal communication, 11 September 2014, Magrath Irrigation District (MID) general manager, Magrath AB, Canada.

[21] Braun, E., Personal communication, 21 August 2014, Western Irrigation District (WID) general manager, Strathmore AB, Canada.

[22] Harrold, A., Personal communication, 18 September 2014, Lethbridge Northern Irrigation District (LNID) general manager, Lethbridge AB, Canada.

[23] Phillips, R., Personal communication, 12-14 August 2014, Bow River Irrigation District (BRID) general manager, Vauxhall AB, Canada.

[24] Tamminga, J., Personal communication, 25 August 2014, St Mary River Irrigation District (SMRID)'s manager of operations, Lethbridge AB, Canada.

[25] ZoBell, G., Personal communication, 24 September 2014, Raymond Irrigation District (RID) general manager, Raymond AB, Canada.

[26] Anonymous participant, Personal communication, 9 September 2014, Eastern Irrigation District (EID) interviewee, Brooks AB, Canada.

[27] Draper, A. J., Lund, J. R., Optimal Hedging and Carryover Storage Value. Water Resources Planning and Management, American Society of Civil Engineering, 130(1), pp. 83-87, 2004.

[28] Lund, J. R., Developing seasonal and long-term reservoir system operation plans using HEC-PRM, U.S. Army Corps of Engineers (USACE), Hydrologic Engineering Center: Davis, pp. 7-50, 1996.

[29] Beard, L. R., Johnson, W. K., Kubik, H. E., Morris, E. C., Pabst, A. F., Reservoir System Analysis for Conservation (Volume 9). Hydrologic Engineering Methods for Water Resources Development, U.S. Army Corps of Engineers (USACE), Hydrologic Engineering Center: Davis, 1977.

[30] Hashimoto, T., Stedinger, J. R., and Loucks, D. P., Reliability, resilience, and vulnerability criteria for water resource system performance evaluation. Water Resources Research, 18(1), pp. 14-20, 1982.

[31] Gallagher, C., Personal communication, 11 September 2014, Taber Irrigation District (TID) general manager, Taber AB, Canada.

[32] Alberta Environment and Sustainable Resource Development's employee, Personal communication, 29 August 2014, Operations Technologist, Calgary AB, Canada.

[33] Alberta Agriculture and Rural Development (AARD). Alberta Irrigation Management Model Web Site, www.agriculture.alberta.ca/acis/imcin/ aimm.jsp 